\title{
INTELLECTUAL GEOINFORMATION SYSTEM FOR EARTH SCIENCES
}

\author{
Alexander Beriozko, Alexei Lebedev, Anatoly Soloviev, \\ Roman Krasnoperov, Alena Rybkina \\ Institution of the Russian Academy of Sciences Geophysical Centre of RAS (GC RAS) \\ 3 Molodezhnaya st., Moscow, 119296, Russian Federation \\ Ph.: +(7)4959300546, fax: +(7)4959300506, e-mail: a.berezko@gcras.ru
}

\begin{abstract}
A new technology was elaborated, combining a geoinformation system (GIS) and GISoriented algorithmic methods of artificial intellect (AI).

Numerous thematic layers for geosciences, obtained from Russian and international scientific sources, were imported into the GIS.

Technology and software for integration of AI methods within the GIS in the form of the Centralized Catalogue of Geodata Processing Algorithms (CCGPA) was developed.

A GIS visualization subsystem was created to provide interaction between the GIS and its users. It performs geodata layers visualization, map operations, geodata set management, execution of CCGPA-stored algorithms and representation of application results.
\end{abstract}

Keywords: geoinformation system, geodata, Earth sciences, artificial intellect.

\section{Introduction}

The fundamental problem of complex analysis of georeferenced data (geodata) is the development of a geographic information system (GIS) and artificial intellect (AI) for the creation of an integrated geinformation environment for thematic data retrieval, storage, and processing. The present research is aimed at the integration of data on geography, geology, geophysics, geoecology, and other Earth sciences in the comprehensive problem-oriented GIS including the intellectual environment for geodata analysis [1].

The main goals of the present research are:

\section{Materials and methods}

- The development of an intellectual GIS for Earth sciences;

- Creation of new AI methods and algorithms for recognition, classification and clusterisation and their integration with the GIS environment and geodata bases.

ArcGIS 9.3.1 software package developed by Environmental Systems Research Institute (ESRI) was used for the creation of the basic GIS environment.

Numerous thematic layers for geosciences were obtained from Russian and international scientific sources and imported to the GIS geodata base.

The main information sources were:

- Institutes of the Russian Academy of Sciences (RAS);

- World Data Centers (WDC) of the World Data System (WDS);

- United States Geological Survey (USGS);

- British Geological Survey (BGS);

- German Research Centre for Geosciences (GFZ);

- Institut de Physique du Globe de Paris (IPGP);

- Institute for Environment and Sustainabilityof the European Commission Joint Research Centre (IES EC JRC);

- International Association of Geomagnetism and Aeronomy (IAGA);

- International Institute for Applied Systems Analysis (IIASA). 
Presently the GIS geodata base includes over 200 thematic layers arranged within 17 data categories including Geodesy and Cartography, Geology, Geophysics, Glaciology, Hydrology, Remote Sensing, Mineral Deposits, Meteorology and Climatology, Pedology, Political Geography, Industry, Agriculture, Biogeography, Ecology. The cartographic base is formed with digital terrain maps at 1:1000 000 scale. All thematic geodata layers are stored as GIS-projects on database servers providing remote access via Internet.

Examples of visualization of different thematic geodata layers in the GIS are shown in Fig. 1.
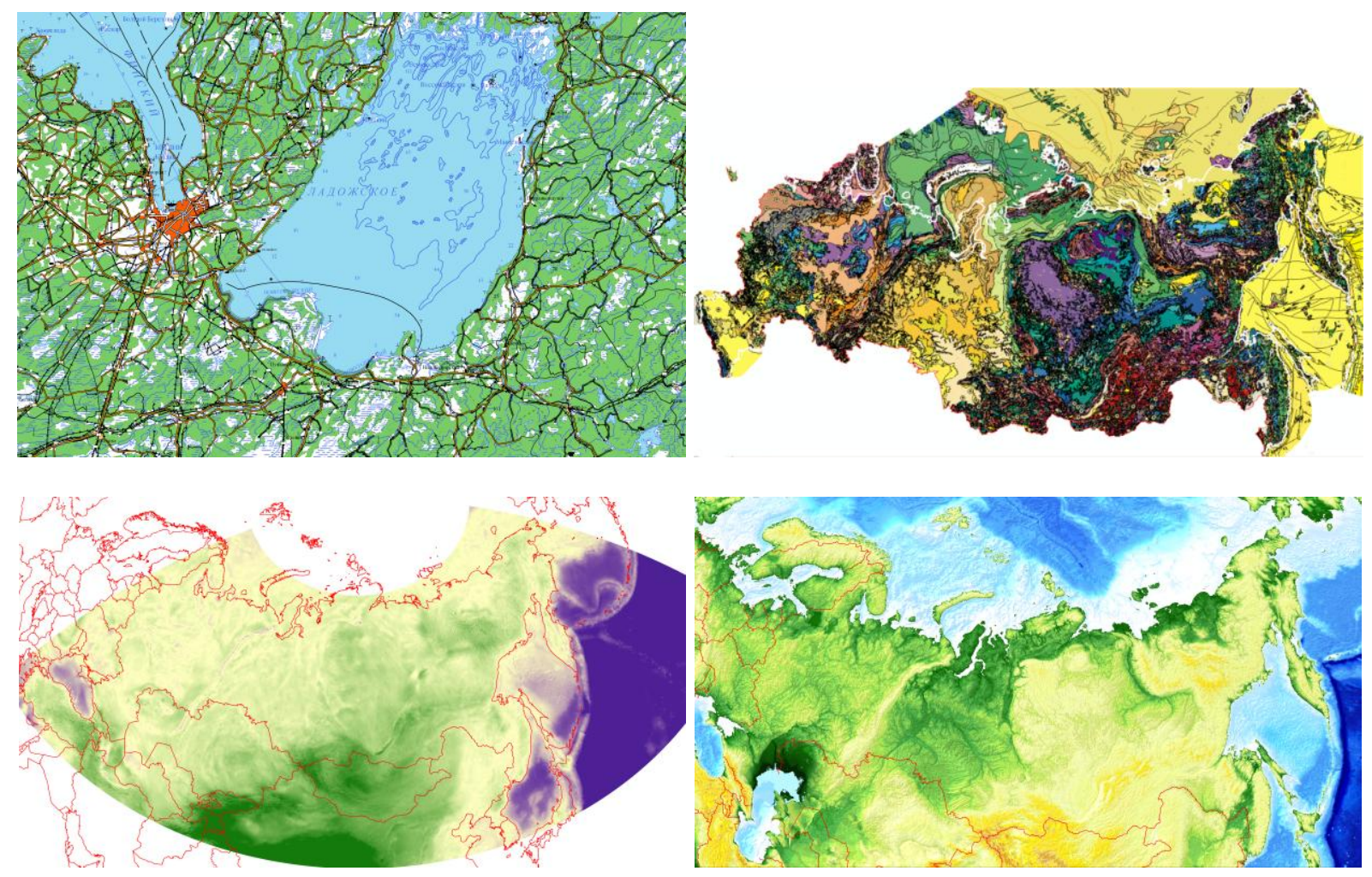

Fig. 1. Visualization of thematic geodata layers in GIS: (top, left to right)

topographic map (fragment, $1: 1000$ 000), geological map (1 : 5000 000);

(bottom, left to right) Bouguer gravity disturbancies (5'), digital elevation model ETOPO1 (1')

In order to integrate AI methods and algorithms within the GIS a new technology was elaborated. This advanced approach is implemented in the form of the Centralized Catalogue of Geodata Processing Algorithms (CCGPA) [2]:

- The CCGPA is a GIS subsystem providing access to algorithms, which are executed centrally by a GIS-server;

- Users can choose available algorithms from the CCGPA or upload new algorithms to the CCGPA themselves;

- Each new algorithm is checked and published by an administrator and becomes available to other users.

The advantages of this technology are:

- Possibility to upload new algorithms to the CCGPA;

- Possibility to execute a sequence of algorithms on several geodata sets;

- Minimal requirements to user workstation: all computations are performed by the server;

- Access to the CCGPA from any Internet node. 
The CCGPA is implemented in three-level architecture as the GIS subsystem [3] on the base of ArcGIS Server technology (Fig. 2).

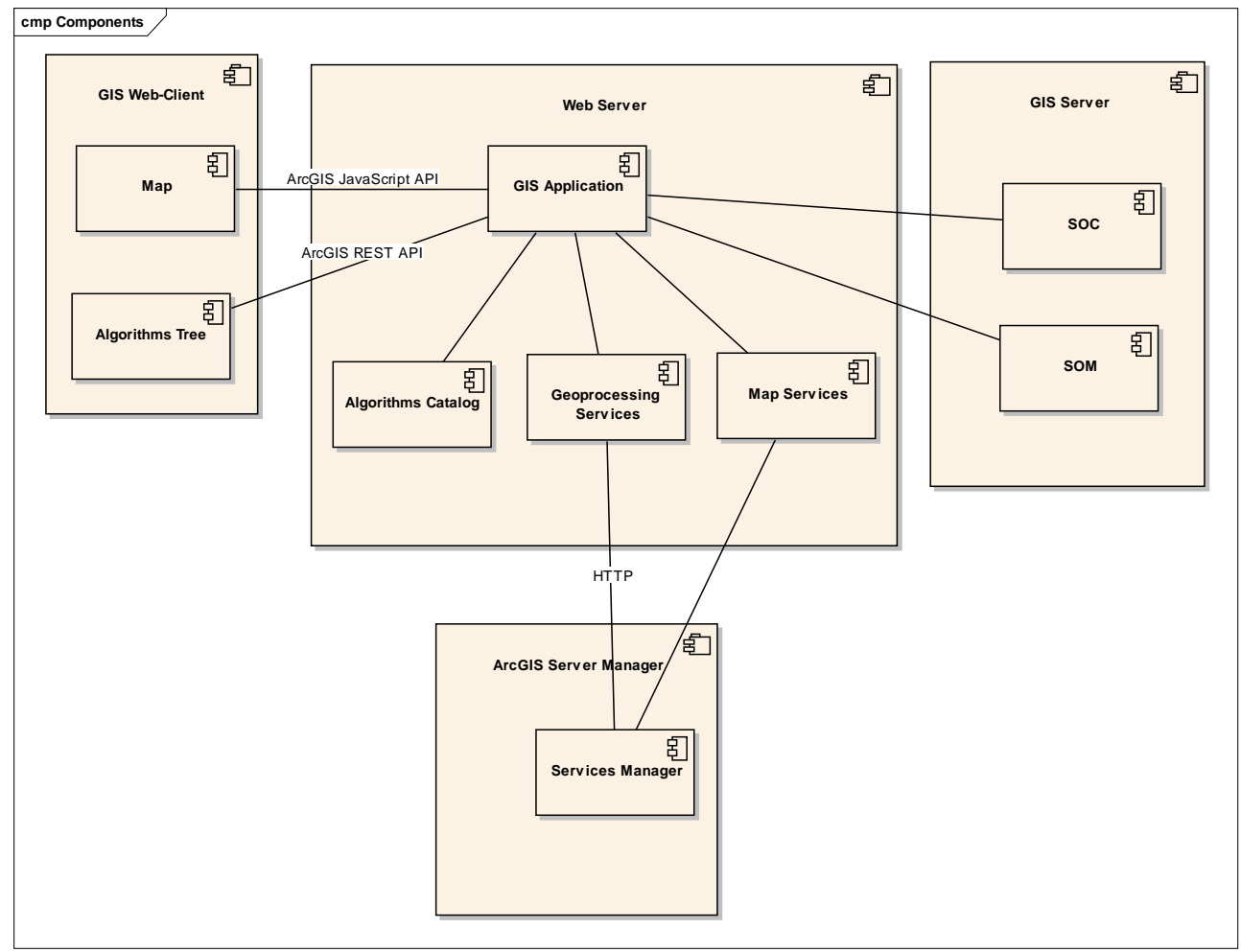

Fig. 2. Architecture of CCGPA

The CCGPA is managed by a GIS administrator using ArcGIS Server Manager application. The administrator publishes algorithms as Geoprocessing Services, which become available to GIS users.

The component Algorithms Catalog is responsible for uploading by users of new algorithms and their storage before inclusion in CCGPA. For uploading algorithms a client application opens a special form.

The client application is implemented via ArcGIS JavaScript API and includes a component for operations with algorithms (Algorithms Tree). When a user launches GIS Application via ESRI REST API, this component receives a list of Geoprocessing Services with the information about them and fills a user's Algorithms Tree.

ArcGIS JavaScript API allows to execute the algorithms with the user-specified parameters and returns the results to the client application for visualization.

Geodata processing is performed by the components Server Object Container (SOC) and Server Object Manager (SOM) of the GIS-server.

To provide interaction between the GIS and its users a GIS visualization subsystem was created. It performs geodata layers visualization, map operations, geodata set management, execution of CCGPA-stored algorithms and representation of application results.

The basic part of the GIS visualization subsystem includes a GIS application, implemented as a web-application. This GIS web-application can be launched at a user's Internet enabled workplace without installation of any additional software. It supports an interface between the GIS, its geodata base, the CCGPA, and remote users.

The user interface of the GIS web-application is represented in a browser window by the following elements (Fig.3):

1. Map window, with minimap subwindow to ease navigation

2. Panel of Instruments for map operations; 
3. Data, Algorithms, Results tabs;

4. Title and Information line.

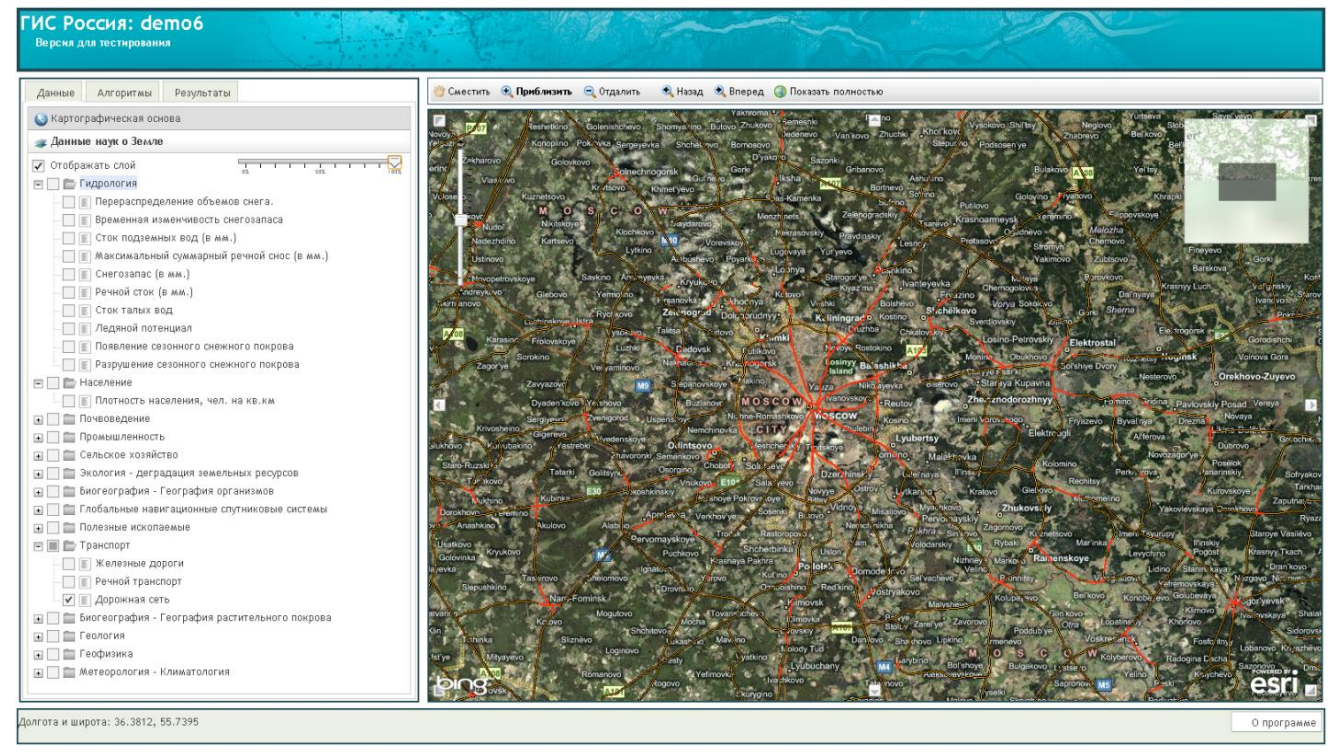

Fig. 3. User interface of GIS web-application

The Data tab contains a tree of thematic geodata layers available for visualization, including conventional signs and legend. A user can switch the layers on and off by placing or removing a tick in the appropriate box.

Geodata layers chosen by a user in the Data are visualized in the Map window.

The Algorithms tab contains a tree of algorithms available in the CCGPA.

The Results tab contains a list of layers created as results of application of chosen algorithms to chosen thematic geodata layers.

It is possible to choose either digital terrain maps at 1:1 000000 scale stored in the GIS geodata base, or web mapping service applications (Google Maps, Bing Maps, Imagery, etc.) as a cartographic base (Fig. 4).

A user can apply to thematic geodata layers visualized in the Map window all instruments and operations contained in the Panel of Instruments (Fig. 5).

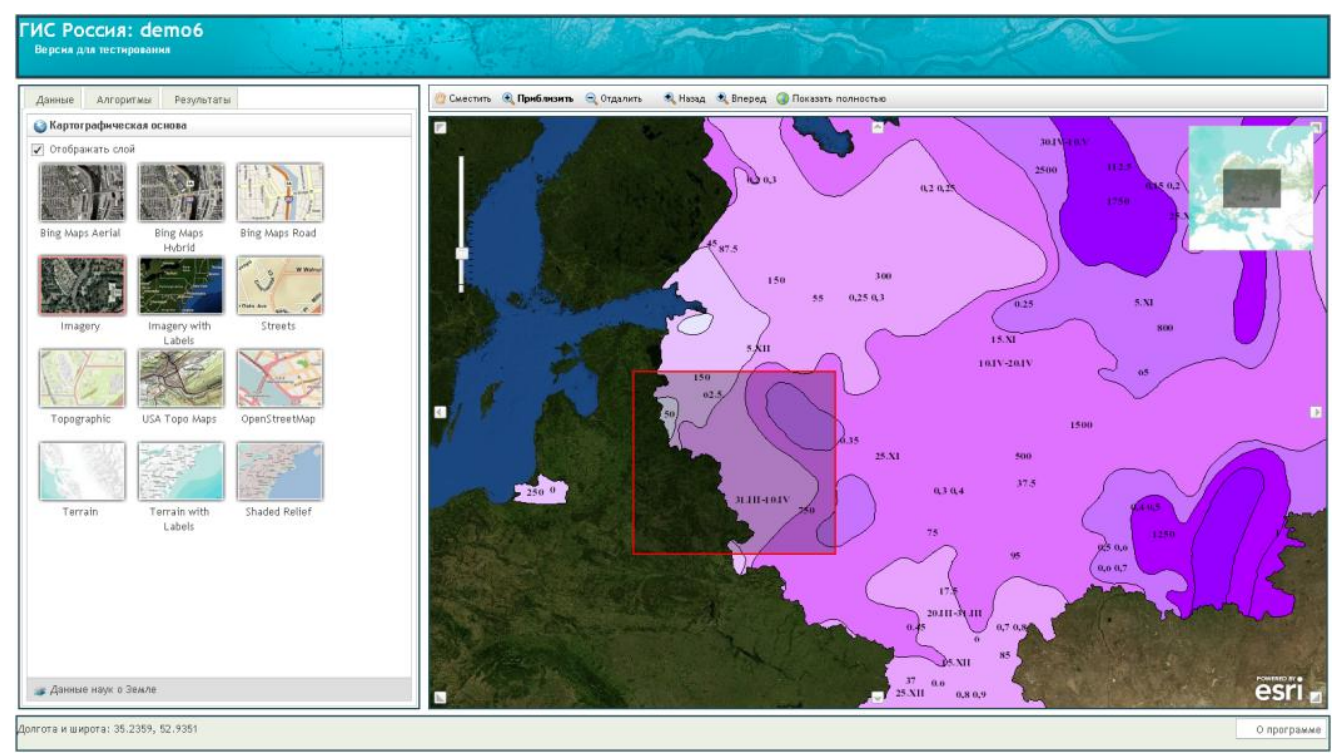

Fig. 4. Choosing a cartographic base 


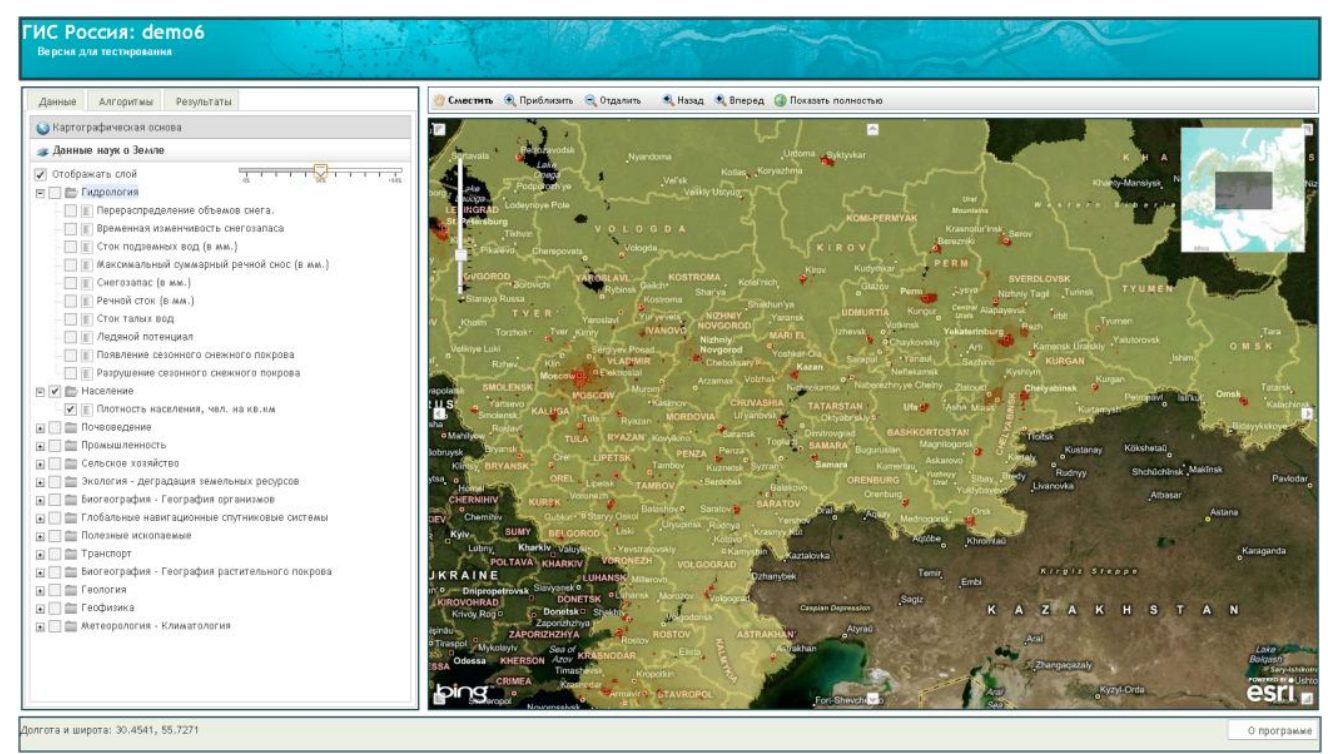

Fig. 5. Overlaying several geodata sets and changing transparency

\section{Results and discussion}

The developed theory and methods of AI must become not only an integral, but the main core of a modern GIS $[4,5]$. At the present time GIS provide only limited opportunities for general analysis of geodata handled. At the same time, among the scientific community, dealing with the Earth sciences data, the requirement of more profound and comprehensive data analyzing and processing is constantly growing. Application of AI methods not only brings the analysis of initial geodata to the higher scientific and practical level, but provides scientifically based recommendations on interpreting the results obtained. The evaluation of natural environment and risk is a task of identification of a complex character of potentially dangerous situation on the basis of huge data volumes of environmental monitoring. The AI methods, developed by the GC RAS, are presently applied to seismology, volcanic activity monitoring, search and interpretation of anomalies in geophysical fields, detecting of signals on various types of times series records, to solving geodynamic problems, etc.

On the base of the CCGPA technology an algorithmic shell was constructed in the frame of the GIS, ensuring the intellectual capacity of GIS environment. The shell comprises a set of customizable algorithms for geodata processing and decision making based on geostatistical and AI methods.

CCGPA is a set of algorithms of universal character bound by the common formal framework. It contains fundamental solutions of classic tasks of data analysis: clustering and search of linear structures in stationary multidimensional arrays, construction of smooth skeletons, search of signals and morphological analysis in time series. Fig. 6 demonstrates the results of application of the $K$-means clustering algorithm stored in the CCGPA to geophysical data sets. 


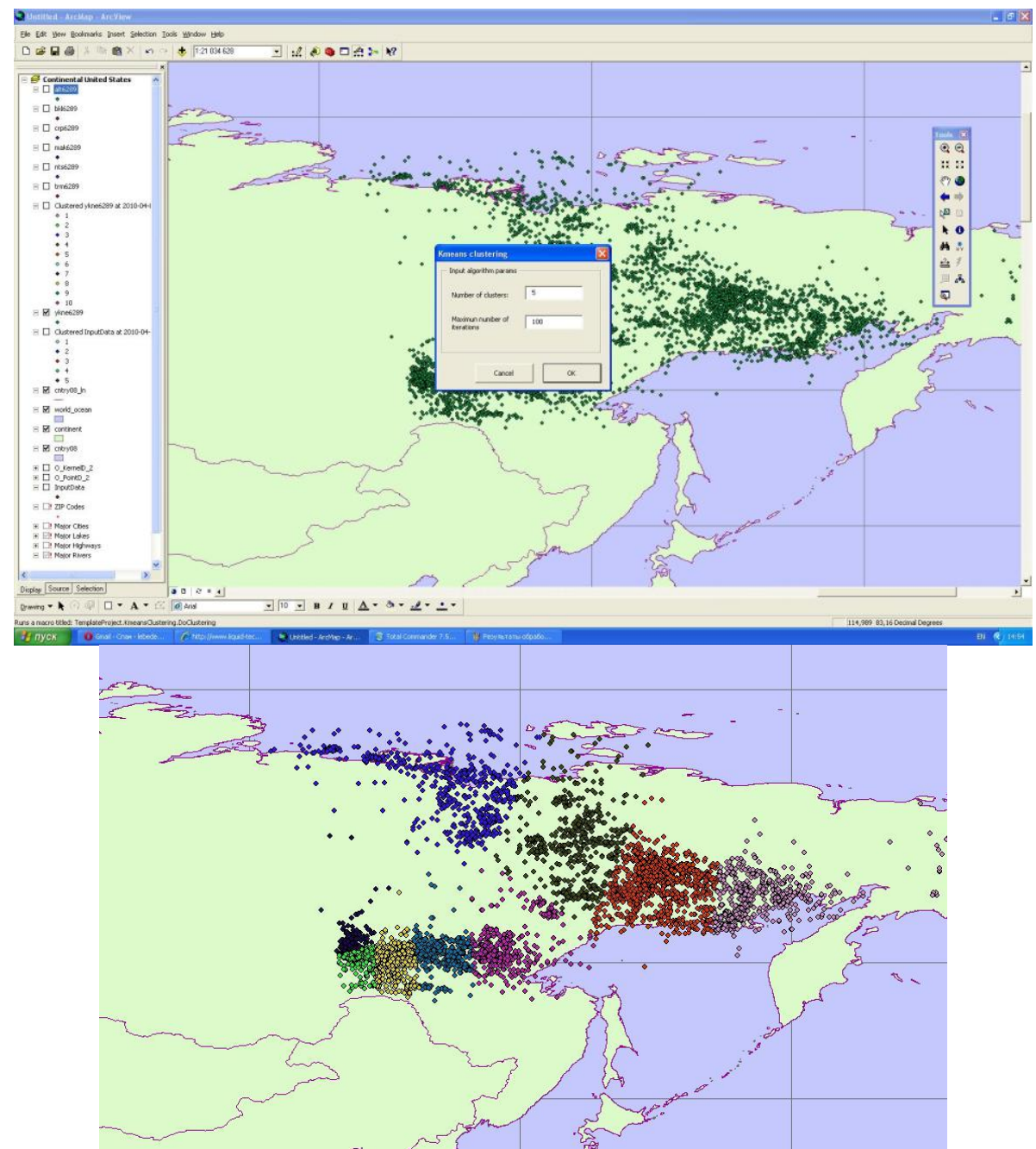

Fig. 6. Application of CCPGA-stored K-means clustering algorithm:

(top) input data (earthquake epicenters, Eastern Siberia, 1962-1989) and algorithm parameters window; (bottom) results (clusters are marked in colors)

\section{Conclusions}

Application and complex integration of AI methods and algorithms within the unified geinformation environment are the key features of the discussed intellectual GIS. GIS technologies, based on generalization and complex processing of geodata, in combination with appropriately adjusted AI algorithms stored in the CCPGA, provide efficient automation of Earth sciences data analysis and forecasting for fundamental and applied scientific research.

The interaction between the GIS and remote users is provided by the GIS visualization subsystem. It includes the GIS application, implemented as the web-application, which can be launched at a user's Internet enabled workplace without installation of any additional software. The GIS visualization subsystem supports an interface between the GIS, its geodatabase, the CCGPA, and remote users. Thus the problem of geodatabase publication and interface between data, CCGP and remote users was solved. 


\section{Bibliography}

1. Березко А.Е., Соловьев А.А., Гвишиани А.Д., Жалковский Е.А., Красноперов Р.И., Смагин С.А., Болотский Э.С. Интеллектуальная географическая информационная система “Данные наук о Земле по территории России" // Инженерная экология. 2008. № 5. С. 32-40.

2. Лебедев А.Ю., Березко А.Е. Создание централизованного каталога алгоритмов обработки геофизических данных // Росс. ж. наук о Земле. 2009. № 11. RE2002. doi:10.2205/2009ES000399. URL: http://elpub.wdcb.ru/journals/rjes/v11/2009ES000399/2009ES000399.pdf.

3. Лебедев А.Ю., Березко А.Е. Создание централизованного каталога алгоритмов обработки геоданных // Геоинформатика. 2010. № 2. С. 67-70.

4. A. Beriozko, A. Soloviev, R. Krasnoperov, A. Rybkina, E. Kedrov, E. Bolotsky. Intellectual analytical geoinformation system "Earth sciences data for the territory of Russia" // Materials of the International Conference "Electronic Geophysical Year: State of the Art and Results" (2009), edited by V. Nechitailenko, GC RAS, Moscow, 117pp., doi:10.2205/2009-REGYconf. 2009ES000407/ P. 27-28.

5. A. Berezko, A. Soloviev, R. Krasnoperov, A. Rybkina. Intellectual analytical geoinformation system "Earth Science Data for the Territory of Russia"// Environment. Technology. Resources: Proceedings of the 7th International Scientific and Practical Conference, Rezekne, June 25-27, 2009. Rēzeknes Augstskola, Rēzekne, RA Izdevniecība. 2009. Vol. 1. Pp. 215-221. ISSN 1691-5402. 